A. Klimczuk, Causes of Crime, [in:] F.F. Wherry (ed.), The SAGE Encyclopedia of Economics and Society, SAGE Publications, Los Angeles 2015, pp. 308-311.

http://doi.org/10.4135/9781452206905.n128

\title{
Causes of Crime
}

Causes of crime are the subject of the etiology of criminal behavior, which is characterized by an interdisciplinary approach. There are many theories attempting to explain the determinants of criminal behavior, a set of acts recognized by criminal law, which emphasize different aspects of this phenomenon.

In the works of ancient philosophers, Homer and Aristotle are indications of the negative mental and physical anomalies that may stimulate individuals to commit crimes. Such concepts are defined as physiognomic and phrenological. In the Middle Ages, a person's ugliness, defined by a crippled and disfigured face, was considered as an indication of the demonological nature, possession by the devil, or being marked by God. This stigma could contribute to frustration, aggression, and crime. Phrenology — popularized in the 18th and 19th centuries by Franz Joseph Gall, a German physician - assumed that the shape of a person's skull shows that person's mental characteristics. Thus, attention was paid to the necessity of studying not only the nature of crime but also the nature of criminals. Although these views were later challenged, they stimulated the development of criminology.

The primary fields of the etiology of criminal behavior are biology, sociology, psychology, and economics. Crimes may also be explained in an evaluative way by political ideologies (conservative, liberal, or radical), which use arguments from any theory to achieve political goals. Any crime may also be seen as a source or as a consequence of political instability.

\section{Biological Theories}

Biological theories seek the causes and circumstances of the crime and social pathology only in the biological factors (e.g., physiological, biochemical, neurological) and genetic factors (inherited biological factors) of human development. Attention is drawn to personality disorders, which can be divided into congenital disorders (psychopathy) or acquired disorders (characteropathy). Examples are oligofrenia, mental illness, and schizophrenia. The causes of crime are also seen in the individual deviations from the average state of mental balance or in its faults, such as low levels of mental development.

This perspective also includes, inter alia, the inheritance of criminal traits by the perpetrators, criminalization by the atypical arrangement of chromosomes, adverse changes in certain parts of the brain, gene-environment interactions, a genetic liability to alcoholism, and prenatal factors (maternal influenza, smoking) — all of which contribute to the criminal act. Such evidence comes from family studies (however, there is no possibility of separating the 
A. Klimczuk, Causes of Crime, [in:] F.F. Wherry (ed.), The SAGE Encyclopedia of Economics and Society, SAGE Publications, Los Angeles 2015, pp. 308-311.

http://doi.org/10.4135/9781452206905.n128

genetic and environmental factors), twin studies (comparing the rate of criminal behavior of genetically identical twins or monozygotic twins and nonmonozygotic, or dizygotic, twins), and adoption studies (comparing the behavior of biological parents and adoptees, who are separated from their parents at birth).

\section{Psychological Theories}

This orientation indicates criminalized factors related to the human mental structure and psychological mechanisms. Such theories focus on family influences (e.g., broken homes, poor child-rearing methods, criminal parents), individual influences (e.g., intelligence, personality, cognitive processes), and the continuity of criminal potential during human development from childhood to adulthood.

Psychoanalysis, founded by Sigmund Freud, considers crimes as the effects of individual emotional reactions, in particular to the family. According to Freud, personality is composed of three parts: the id, ego, and superego. The id represents what we inherit and our drives; it works on the principle of pleasure. The drives of love and death clash inside the id. The ego represents prudence and reason, seeking to achieve realistic objectives, and the defense mechanisms used to avoid anxiety and trouble. The superego represents the social development of the individual and stopping id impulses that are socially condemned. The entire structure of personality is based on the conflict between the superego and the ego, which causes feelings of guilt, which may be related to committing prohibited acts and the fear of losing loved ones. That is why people tend to save themselves from committing crimes. However, individuals can rationalize or justify their guilt by something else before committing a crime. It is assumed here that the offender commits a crime and wants to be caught, because he or she is afraid to commit worse offenses; an individual commits crimes to compensate the unmet needs of the family environment or because he or she wants to get acceptance and the love of others.

There are also different theories of broken homes and attachment theories that focus on the relationship between disrupted families and delinquency. Trauma theories show that the loss of a parent may have a negative impact on the psyche of children. According to life course theories, separation, parental conflict, deteriorated economic situation of the family, and poor child-rearing methods also cause stressful experiences. Selection theories show that broken homes have a negative influence on children because of their lower position in society compared with other families due to parental conflict, criminal or antisocial parents, and low income. 
A. Klimczuk, Causes of Crime, [in:] F.F. Wherry (ed.), The SAGE Encyclopedia of Economics and Society, SAGE Publications, Los Angeles 2015, pp. 308-311.

http://doi.org/10.4135/9781452206905.n128

Behaviorism, as represented by Albert Bandura, assumes that social maladjustment, such as aggression, involves three elements: (1) classical conditioning focuses on a particular external stimulus, such as a quarrel, which causes an aggressive attitude; (2) instrumental conditioning includes new habits gained under the influence of the direct activity of the learner-for example, training 1n targeted violence; and (3) social learning theory assumes that behavior can be learned by observing and imitating others-for example, observation of domestic violence, imitation of the mass media, mistreatment by others, stimulation to aggression, and persuasion by rewards. Contemporary social learning theories are related to child-rearing methods that may predict a child's delinquency. They include factors such as supervision or monitoring of children and the warmth or coldness of emotional relationships.

Humanistic psychology by Gordon Allport, Abraham Masłow, and Carl Rogers assumes that both psychoanalysis and behaviorism treat man as entirely determined by instincts or impulses. Therefore, it is assumed that man is an entity full of good energy, and that life is a process of implementation of possibilities called "full humanity." This process is complicated and involves interferences and inhibitions, such as fear of the world, disbelief in one's creative capabilities, and submission to the pathological patterns of life. These disturbances cause unacceptable behavior like enjoying cruelty, crime, and hate. The only release from such factors allows for the full development of the individual. Therefore, preventing disorders requires recognition of unpleasant tensions, one's recovery from these tensions, and being aware of these issues.

\section{Sociological Theories}

It is assumed here that crimes are social phenomena that result from social, environmental factors at the microlevel (the family, school, peer group, workplace; e.g., terms of socialization), mesolevel (community, village, city; e.g., the processes of industrialization and urbanization), and macrolevel (society, global; e.g., economic crisis, war).

The offenses are treated here as manifestations of social deviance or pathology, understood as a violation of norms and values that have a destructive impact on the community. Whether criminal behavior is accepted as normal or is condemned depends on the social context and culture. The same behavior - for example, the use of firearms - may be perceived differently in different societies.

Robert Merton's anomie theory suggests that deviant behavior arises from inequalities in the social structure, which cause tension between the socially produced needs or expectations 
A. Klimczuk, Causes of Crime, [in:] F.F. Wherry (ed.), The SAGE Encyclopedia of Economics and Society, SAGE Publications, Los Angeles 2015, pp. 308-311.

http://doi.org/10.4135/9781452206905.n128

and the divergent possibilities of meeting them. This state of frustration leads to deviation, which may take the form of recourse to illegal means to achieve the cultural objectives. Anomie theory led to strain theory, propounded by scholars such as Robert Agnew and Albert Cohen. It highlights that people employ crime to reduce or get away from the strain they are experiencing (e.g., to end harassment from others, to take revenge, to steal in order to overcome financial troubles). The main types of strain that lead to crime are (1) others who are blocking the individual's objectives and (2) others who take personal things and values or who represent negative or noxious stimuli. Among the most important goals that may generate strain are money, status or respect, and adolescents' autonomy from adults.

Differential association theory by Edwin Sutherland shows that people learn criminal behavior in the process of symbolic interactions with primary groups. Crime is the result of learning more norms and values associated with criminal activity during socialization than those with noncriminal activity. Acquiring these values and behaviors depends on the duration, frequency, and intensity of links to criminal behavior.

Theories of delinquency subcultures by Albert Cohen and of differential opportunity by Richard Cloward and Lloyd Ohlin argue that criminal behavior, including involvement with gangs, is derived from the strain caused by the inability to achieve socially valued goals. This inability is due to the cultural imbalance and social status of the individual.

Social control theory by Travis Hirschi assumes that the propensity to conformist behavior is not an innate human trait, so scholars should examine why people obey the law and behave in accordance with the norms. The course of socialization is important here because the process of learning approved behavior requires an emotional bond with others and an internally consistent set of norms, which distinguishes the so-called normal people from harmful people. Effective control requires undisturbed socialization (interiorization of self-control), positive support of the individual by the primary group and its ability to control the behavior, and a coherent and comprehensible system of norms and values. Enforcement of control occurs with social disorganization, loosening of social ties, and individuals not meeting others' expectations (e.g., when a person commits acts that are considered as crimes).

Labeling theory by Howard Becker and Erving Goffman focuses on describing those seen as deviant from standard cultural norms (e.g., criminals, the mentally ill, homosexuals) and assumes that formal social reaction to the deviated individual contributes to deepening the individual's maladjustment symptoms. Calling some behavior as deviant and its perpetrators as deviants results in the adoption of this imposed role with behavior consistent with this role. An 
A. Klimczuk, Causes of Crime, [in:] F.F. Wherry (ed.), The SAGE Encyclopedia of Economics and Society, SAGE Publications, Los Angeles 2015, pp. 308-311.

http://doi.org/10.4135/9781452206905.n128

extreme effect of stigma may be the exclusion of a deviant from the group and social isolation, entailing total identification with the imposed role.

Marxist theories argue that the capitalist class that has the means of production (e.g., businesses) has the greatest power. These entities use their power to construct laws that increase their profits, criminalize the behavior of lower-class members, and ignore or mildly sanction the actions of businesses, such as pollution. Feminist theories highlight how gender differences may lead to crime. They focus on examining why males are more engaged in most types of crime than females and on the differences in the causes of male and female crime.

\section{Economic Theories}

Cesare Beccaria and Jeremy Bentham were precursors of rational choice theorists, focusing on improving criminal justice and deterring individuals from crime. They claim that if the benefits are higher than the costs, then people will commit a crime. Thus, people have a free will to decide whether to commit crimes. The rational reaction of society to crime is to achieve a situation where crime does not pay or to increase the costs of crime and reduce its benefits.

Similar ideas were developed by Gary Becker, a Nobel Prize-winning economist, and scholars such as Isaac Ehrlich, Steven Shavell, and Richard Posner. It is assumed that the individuals choose between criminal behavior and lawful behavior, calculating factors such as the expected gains from crime compared with earnings from legal employment and the exposure of being caught and convicted. Additional variables include gender, age, intelligence, income, and education. In this model, it is recognized that the victims as well as the officers of justice seek to optimize the benefits or choose the solution that most effectively implements their preferences.

The purpose of criminal law is considered here to ensure greater happiness of people than would be possible without it. In economic terms, each person is a potential criminal and a victim. Choices of criminals are determined by the benefits of the crime, the direct cost of its commission, the cost spread over time (e.g., loss of reputation among friends when the case is exposed, the reduced possibility of taking legal work), the opportunity costs (profit from actions that can be taken in the time frame of a crime), and the expected cost of punishment (i.e., there is no assurance that the offender will be caught). These models, in contrast to other theories, explain the occurrence of recidivism. Choices of potential victims include activities to protect against crimes of others - for example, the installation of door locks, avoiding night walks, and distrust of strangers. 
A. Klimczuk, Causes of Crime, [in:] F.F. Wherry (ed.), The SAGE Encyclopedia of Economics and Society, SAGE Publications, Los Angeles 2015, pp. 308-311.

http://doi.org/10.4135/9781452206905.n128

Public choice concerns the use of cost-benefit analysis to assess alternative policies to reduce crime. Security is seen here as a public good, which includes charges for the maintenance of a system for ensuring the safety of citizens and funding the police and justice. Security requires the prosecution and punishment of offenders by using coercion and control by the police. For example, a state determines the probability of trial (by the quantum of expenditures on police, prosecution, and the courts) and the amount of penalty (through provisions of the criminal code and the expenditure on enforcement of judgments). The economic approach justifies the existence of a prison sentence, regardless of the effects of resocialization, due to the lack of payment of fines by multiple perpetrators and the inadequacy of financial penalties for serious crimes.

Andrzej Klimczuk

Warsaw School of Economics

See Also: Career Criminals; Crime Prevention; Criminal Record and Employment;

Geography and Crime

\section{Further Readings}

Barlow, Hugh D., and David Kauzlarich. Explaining Crime: A Primer in Criminological Theory. Lanham, MD: Rowman \& Littlefield Publishers, 2010.

Brown, Stephen E., Finn-Aage Esbensen, and Gilbert Geis. Criminology: Explaining Crime and Its Context, 7th ed. New Providence, NJ: LexisNexis, 2010.

Guarino-Ghezzi, Susan and A. Javier Trevino, eds. Understanding Crime: A Multidisciplinary Approach. Newark, NJ: LexisNexis, 2005.

Mednick, Sarnoff A., Terrie E. Moffitt, and Susan A. Stack, eds. The Causes of Crime: New Biological Approaches. Cambridge, NY: Cambridge University Press, 1987.

Miller, J. Mitchell, ed. 21st Century Criminology: A Reference Handbook. Thousand Oaks, CA: Sage, 2009.

Welsh, Brandon, David P. Farrington, and Lawrence W. Sherman. Costs and Benefits of Preventing Crime. Boulder, CO: Westview Press, 2001.

Winter, Harold. The Economics of Crime: An Introduction to Rational Crime Analysis. London: Routledge, 2008. 